\title{
LONG-TERM POLLEN MONITORING EXPERIMENTS FOR THE PERIOD 1994-2008 IN THE RILA MOUNTAINS, BULGARIA
}

\author{
Spassimir Tonkov ${ }^{*}$, Elissaveta Bozilova ${ }^{1}$, Dolja Pavlova$^{1}$, Ivan Raev $^{2}$ \\ ${ }^{1}$ Department of Botany, Faculty of Biology, Sofia University “St. Kliment Ohridski”, 1164 Sofia, Bulgaria, \\ stonkov@abv.bg*Corresponding author,bozilova@biofac.uni-sofia.bg,pavlova@biofac.uni-sofia.bg \\ ${ }^{2}$ Forest Research Institute, Bulgarian Academy of Sciences, 1756 Sofia, Bulgaria, bwp@dir.bg
}

\begin{abstract}
The annual pollen influx in the altitudinal zone 1800-2050 $\mathrm{m}$ a.s.l. produced by plant communities in the coniferous and subalpine vegetation belts of the northwestern Rila Mts. was analyzed for the period 1994-2008. The results from the five pollen traps placed on south and north slopes of a ridge revealed the dominance of Pinus diploxylon-type (Pinus mugo, Pinus sylvestris) and relatively constant presence of Picea abies and Pinus peuce pollen, with the exception in years of abundant flowering (1997, 1999, 2003 and partly 2005). The species Fagus sylvatica which grows at lower altitudes showed very good capabilities of pollen dispersal upslope. The trapping results indicated a cyclicity in the flowering of beech, with maximal pollen influx values in years 1994, 1999, 2005 and 2007, most probably dependent on the local climatic conditions. Pollen of deciduous trees such as Quercus, Carpinus betulus, Corylus, Alnus, Betula, although in less quantities, was also recorded in the traps. The herb component constituted only a small part of the total annual pollen influx. The results from long-term pollen trapping experiments could be applied to monitor the future trends in forest development in relation to climate change and local disturbances.
\end{abstract}

Key words: pollen monitoring, pollen traps, pollen influx, trees, Rila Mts., Bulgaria

Özet

Rila Dağ1 1800-2050 m yükseltileri arasındaki zirve altı kuşaktaki bitki toplumlarının ve iğne yapraklı ormanların 1994-2008 yılları arasındaki polen dağılımları incelenmiştir. Sırtların kuzey ve güney bakılarından toplanan toplam 5 adet polen kapanlarından elde edilen bulgulara göre en hâkim türlerin Pinus diploxylon-tipi (Pinus mugo, Pinus sylvestris) ve yoğun çiçeklenme yılları olan (1997, 1999, 2003 ve 2005 yılları hariç) nispeten Picea abies ve Pinus peuce polenlerinin sürekli olarak varlık gösterdiği tespit edilmiştir. Alt yükseltilerde yayılış gösteren Fagus sylvatica'nın yamaç yukarı yönde yoğun bir polen saçımı potansiyeli gösterdiği gözlemlenmiştir. Polen kapanlarıyla elde edilen bulgulara göre, kayın polenlerinin dağılımlarında, büyük ihtimalle mikro iklime bağlı olarak, bilhassa azami çiçeklenmenin gerçekleștiği 1994, 1999, 2005 ve 2007 y1llarında döngüselliğin meydana geldiği görülmüștür. Quercus, Carpinus betulus, Corylus, Alnus, Betula gibi yapraklı türlerin polenlerine de az miktarda da olsa rastlanmıştır. Otsu türlerin polenlerine yıllık toplam polen miktarları arasında çok düşük bir oranda rastlanmıştır. Uzun dönemli polen izleme çalışmaları ile iklim değişikliği ve yerel orman zararlarından ormanlarda doğacak değişikliklerin izlenmesi mümkün olabilecektir.

Anahtar Kelimeler: Polen izleme, Polen kapanı, Polen saçımı, Ağaçlar, Rila Dağı, Bulgaristan.

\section{INTRODUCTION}

Pollen monitoring experiments provide information on the recent state of plant ecosystems as the pollen rain produced is dependent on different ecological factors. The relationship modern vegetation/pollen is determined by the pollen production of the individual species and their ecophysiological characteristics, which in turn are linked with temperature and humidity for the corresponding period of observation (Hicks 2001). The use of pollen traps enables to calculate annual pollen deposition of individual taxa with 
confidence (pollen accumulation rates or pollen influx) and to relate the inter-annual variation in pollen deposition to seasonal meteorological changes (Hicks 1996, van der Knaap et al. 2010). The main advantage of pollen traps over surface moss samples is that the former provide an independent pollen record for each taxon, unaffected by changes in abundance of other taxa (Seppa and Hicks 2006).

In forest ecosystems particular focus is placed on the tree-lines as those are regarded as one of the most climate-sensitive ecotone zones in the landscape to changes in environmental conditions. Pollen monitoring investigations are of basic relevance for a better understanding of the long-term ecological processes driving the spread, establishment and persistence of individual tree populations. Apart from their scientific interest, the results are indispensable for modern forest management based on scientifically built scenarios of future environmental change (Birks 1996).

The Pollen Monitoring Programme in Europe was launched in 1996 (Giesecke et al. 2010) and within short period of time the first observations based on results from the network of standardized pollen traps were published (Hicks et al. 2001). The Bulgarian palynologists were among the first who joined this programme and until now pollen monitoring experiments for different periods of observation were conducted in the Rila (Tonkov et al. 2001, 2004, 2009), the Western Rhodopes (Lazarova et al. 2006), the Central Stara Planina (Atanassova 2007) and the Strandzha (Filipova-Marinova et al. 2007) mountains, and in the lowlands of northeast Bulgaria (Bozilova et al. 2012). Moreover, data from the analyses of pollen traps and surface moss samples were included in several review papers dealing with specific problems of pollen monitoring on a European scale (Filipova-Marinova et al. 2010, Pardoe et al. 2010, Pidek et al. 2010).

The Pollen Monitoring Programme has also expanded in other Balkan countries including research activities in Greece (Gerasimidis et al. 2006) and in the European part of Turkey (Karlioglu et al. 2014, 2015).

The present paper is an attempt to summarize and discuss the results from long-term pollen trapping studies in the coniferous forests of the Rila Mts. in the altitudinal zone 1840-2050 $\mathrm{m}$ a.s.l. in relation to the modern vegetation and climatic factors (temperature and precipitation). Such a valuable information can also serve as a basis for interpreting fossil pollen assemblages obtained from mountainous areas (Hicks et al. 2001).

\section{MATERIAL AND METHODS}

\section{The study area and field collection}

The first pollen traps in the Rila Mts. were placed in the autumn of 1993 (Tonkov et al. 2001). Until 2005 eleven pollen traps were placed in the northwestern part of the mountain in different locations following the EPMP guidelines (Hicks et al. 1996). The location of the traps was selected so that pollen deposition would reflect the local picture of the modern vegetation and provide information about pollen production, dispersal and deposition within different vegetation belts and plant communities. Unfortunately, several traps disappeared and the subsequent efforts to restore them were unsuccessful. The rest of the pollen traps functioned for different periods of time due to objective reasons. The results from five traps with the longest series of data observation within the period 
1994-2008 are presented and discussed

(Figure 1 and 2).

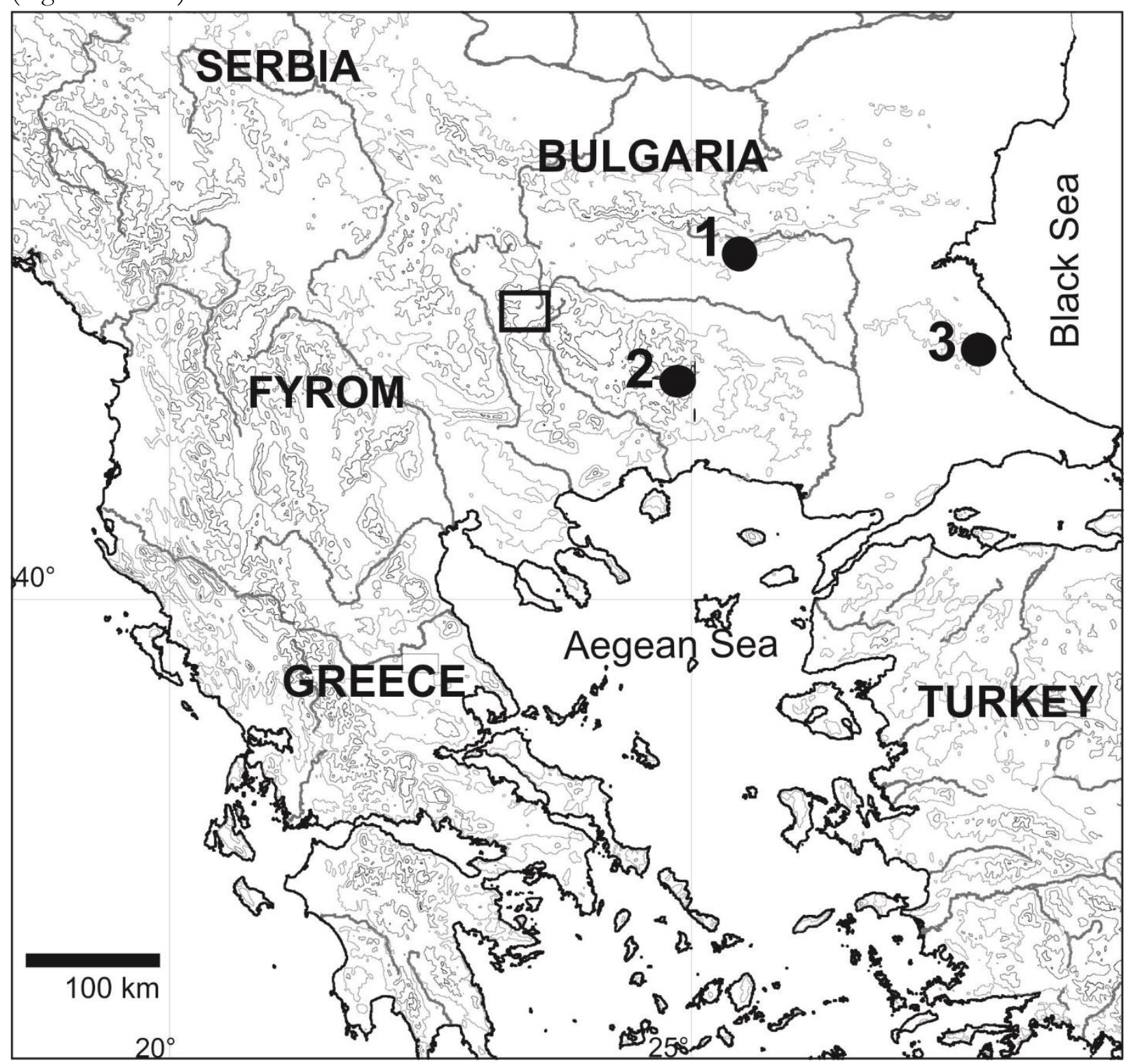

Figure 1. Map of the Balkan peninsula showing the location of the Rila Mts. (open rectangle) and other pollen trapping studies (closed circles) discussed in the text: 1 Central Stara Planina Mts. (Atanassova 2007); 2 Western Rhodopes Mts. (Lazarova et al. 2006); 3 Strandzha Mts. (Filipova et al. 2007). 


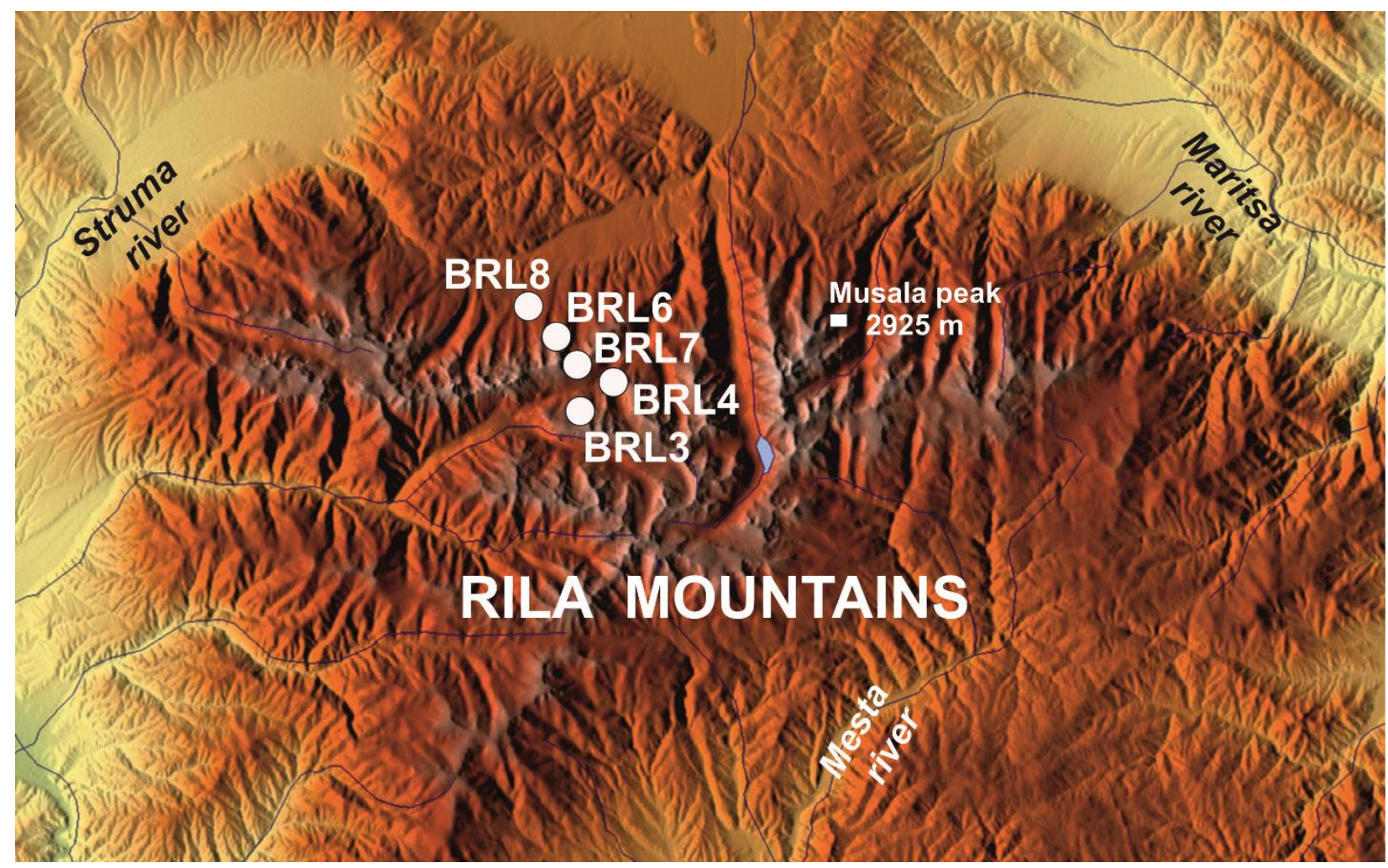

Figure 2. A morphographic map of the Rila Mts. with the location of the pollen traps (open circles).

The modern vegetation in the Rila Mts. (Musala peak, $2925 \mathrm{~m}$ ) is distributed in several altitudinal belts which are clearly distinguished: the lowermost xerothermic oak belt (up to 600-700 $\mathrm{m}$ a.s.l.); the oak and hornbeam mesoxerophilous belt (600-1000 $\mathrm{m}$ a.s.l.) with Quercus dalechampii Ten. and Carpinus betulus L. as the main tree species; the beech belt (1000-1600 $\mathrm{m}$ a.s.l.) being fragmented at many places and dominated by single-dominant or mixed communities of Fagus sylvatica L.; the vast coniferous belt (1600-(2000)2200 m a.s.l.) dominated by Picea abies (L.) Karst) and the Balkan endemic Pinuspence Griseb. with an admixture of Pinus sylvestris L. and Abies alba Mill.; the subalpine belt (2200-2500 $\mathrm{m}$ a.s.l.) where thick formations of Pinus mugo Turra and Juniperus sibirica Burgsd. exist, and the alpine belt above $2500 \mathrm{~m}$ with herbaceous vegetation (Tonkov et al. 2001).

On a slope with south exposure were placed two traps - BRL3 and BRL4 (Figure 2). The trap BRL3 was placed at $1840 \mathrm{~m}$ a.s.l. in an opening within a mixed coniferous forest. The proportions of the main arboreal species around the sampling site are Pinus peuce (30\%), Pinus sylvestris (20\%), Picea abies (20\%), Abies alba (10\%). The other trap BRL4 was placed at $1900 \mathrm{~m}$ a.s.l. in an open area of the ecotone zone between the coniferous forests and the subalpine belt. The proportions of the main tree species near to the sampling site are Pinus mugo (25\%), Pinus sylvestris (15\%), Picea abies (10\%), Pinus pence (5\%), Betula pendula Roth. (5\%) and a rich layer of herbs (Table 1). 
Table 1. Geographical coordinates of the pollen traps in the Rila Mts. and description of the surrounding vegetation.

\begin{tabular}{|c|c|c|c|c|}
\hline $\begin{array}{l}\text { Trap } \\
\text { code }\end{array}$ & $\begin{array}{c}\text { Coordin } \\
\text { ates }\end{array}$ & $\begin{array}{c}\text { Eleva } \\
\text { tion }\end{array}$ & Vegetation at the study site & $\begin{array}{c}\text { Forest } \\
\text { opening }\end{array}$ \\
\hline BRL3 & $\begin{array}{c}42^{\circ} 09^{\prime} 43.5 \\
9 " \mathrm{~N} \\
23^{\circ} 24^{\prime} 44.7 \\
5^{\prime \prime} \mathrm{E}\end{array}$ & $\begin{array}{c}1840 \\
\text { m, } \\
\text { south } \\
\text { slope }\end{array}$ & $\begin{array}{l}\text { Small opening within a mixed } \\
\text { coniferous forest composed of Pinus } \\
\text { peuce }(30 \%) \text {, P. sylvestris (20\%), Picea abies } \\
(20 \%), \text { Abies alba }(10 \%) \text {, Juniperus sibirica } \\
(5 \%) \text {; dwarf shrubs : Chamaecytisus } \\
\text { austriacus, Chamaespartium sagittale, } \\
\text { Vaccinium myrtillus; herbs: Lu₹ula sylvatica, } \\
\text { Poa nemoralis, Melampyrum sylvaticum, } \\
\text { Acinos alpinus, etc. }\end{array}$ & $10 \mathrm{~m}$ \\
\hline BRL4 & $\begin{array}{c}42^{\circ} 09^{\prime} 58.4 \\
7 " \mathrm{~N} \\
23^{\circ} 24^{\prime} 57.2 \\
6^{\prime \prime} \mathrm{E}\end{array}$ & $\begin{array}{c}1900 \\
\text { m, } \\
\text { south } \\
\text { slope }\end{array}$ & $\begin{array}{l}\text { Open area in the ecotone zone between } \\
\text { the coniferous and subalpine vegetation } \\
\text { belts; Pinus mugo (25\%), P. sylvestris } \\
(15 \%) \text {, Picea abies (10\%), Pinus peuce (5\%), } \\
\text { Betula pendula (5\%), Alnus viridis (3\%), } \\
\text { Populus tremula (2\%); dwarf shrubs: } \\
\text { Vaccinium myrtillus and V. uluginosum; } \\
\text { herbs: Festuca valida, Calamagrostis } \\
\text { arundinaceae, Geum coccineum, Centaurea } \\
\text { nervosa, Cirsium appendiculatum, Rumex } \\
\text { alpinus, etc. }\end{array}$ & $80 \mathrm{~m}$ \\
\hline BRL8 & $\begin{array}{c}42^{\circ} 12^{\prime} 38^{\prime \prime} \\
\mathrm{N} \\
23^{\circ} 24^{\prime} 23^{\prime \prime} \\
\mathrm{E}\end{array}$ & $\begin{array}{c}1800 \\
\mathrm{~m}, \\
\text { north } \\
\text { slope }\end{array}$ & $\begin{array}{l}\text { Small opening within a mixed } \\
\text { coniferous forest composed of Picea } \\
\text { abies }(70 \%) \text {, Pinus pence (20\%), Betula } \\
\text { pendula, Salix caprea, Pinus sylvestris; dwarf } \\
\text { shrubs: V accinium myrtillus, V. uliginosum, } \\
\text { Bruckenthalia spiculifolia; herbs: } \\
\text { Deschampsia flexuosa, Potentilla erecta, } \\
\text { Luzula sylvatica, Caltha palustris, Veratrum } \\
\text { album, etc. }\end{array}$ & $10 \mathrm{~m}$ \\
\hline BRL6 & $\begin{array}{c}42^{\circ} 12^{\prime} 23^{\prime \prime} \\
\mathrm{N} \\
23^{\circ} 24^{\prime} 19^{\prime \prime} \\
\mathrm{E}\end{array}$ & $\begin{array}{c}1900 \\
\text { m, } \\
\text { north } \\
\text { slope }\end{array}$ & $\begin{array}{l}\text { Open area in the ecotone zone between } \\
\text { the coniferous and subalpine vegetation } \\
\text { belts; Pinus mugo (50\%), stands of Pinus } \\
\text { peuce, Picea abies and Juniperus sibirica; } \\
\text { dwarf shrubs: Vaccinium myrtillus, V. } \\
\text { vitis-idaea; herbs: Calamagrostis } \\
\text { arundinaceae, Deschampsia caespitosa, } \\
\text { Hypericum perforatum, Juncus conglomeratus, } \\
\text { Campanula sparsa, Senecio nemorensis, etc. }\end{array}$ & $30 \mathrm{~m}$ \\
\hline BRL7 & $\begin{array}{c}42^{\circ} 11^{\prime} 53^{\prime \prime} \\
\mathrm{N} \\
23^{\circ} 24^{\prime} 28^{\prime \prime} \\
\mathrm{E}\end{array}$ & $\begin{array}{c}2050 \\
\mathrm{~m}, \\
\text { north } \\
\text { slope }\end{array}$ & $\begin{array}{l}\text { Small opening within the subalpine belt } \\
\text { dominated by Pinus mugo and herbs: } \\
\text { Festuca valida, Deschampsia caespitosa, } \\
\text { Anthoxantum odoratum, Silene vulgaris, } \\
\text { Campanula sparsa, Arenaria biflora, } \\
\text { Leontodon autumnale, Gentianella bulgarica, } \\
\text { etc. }\end{array}$ & $5 \mathrm{~m}$ \\
\hline
\end{tabular}


On a slope with north exposure were placed three traps - BRL8, BRL6 and BRL7 (Figure 2). The trap BRL8 was placed at $1800 \mathrm{~m}$ a.s.l. in a small opening within a mixed coniferous forest composed of Picea abies (70\%) and Pinus peuce (20\%), with single trees of Betula pendula, Salix caprea L. and Pinus sylvestris. The next trap BRL6 was placed at $1900 \mathrm{~m}$ a.s.l. in an open area just above the tree-line where groups of Pinus mugo (50\%) with some Pinus pence, Picea abies and Juniperus sibirica are found. The last trap BRL7 was placed at $2050 \mathrm{~m}$ a.s.l. within the subalpine belt in an opening surrounded by stands of Pinus mugo (Table 1).

Information about the climatic conditions in the study area for the period of observation (1994-2008) was obtained from the nearest Research Station Ovnarsko. The mean annual temperature (MAT) and mean annual precipitation (MAP) values for each year are indicated on the relevant diagrams (Figures 3-7).

\section{Laboratory treatment and presentation of results}

The pollen traps were emptied every autumn. The laboratory preparation of the trap contents for pollen analysis followed the standard treatment (Faegri and Iversen 1989). Before the preparation of the trap contents 3 Lycopodium tablets (13500/13911/11500 spores each) dissolved in distilled water were added (Stockmarr 1971) followed by the removal of excess material and water by sieving and centrifuging. A pollen sum of around 500 arboreal grains was achieved and at least 50 Lycopodium spores were counted per sample. The identification of the pollen grains and spores was performed to the lowest possible taxonomic level using the reference collection of the Department of Botany, the pollen keys in Faegri and Iversen (1989), Moore et al. (1991) and Beug (2004). The annual pollen influx (PI, grains $\mathrm{cm}^{-2}$ year $^{-1}$ ) was calculated using the sample size of 19.6 $\mathrm{cm}^{2}$ (the area of the trapping hole). The PI of the most common trees/shrubs (AP) and herbs (NAP) was graphically presented using the software product TGView ver. 1.17.5 (Grimm 2011) (Figures 3-7). A summary graphic with the PI values for Fagus and Picea from all pollen traps was also constructed (Figure 8).

\section{RESULTS}

\section{South slope - pollen traps BRL-3 and BRL-4}

Trap BRL-3 has functioned for the entire period of observation (1994-2008). The total PI varies between 7500 and 27700 grains $\mathrm{cm}^{-2}$ year ${ }^{-1}$. The highest values are established for years 1995, 1999, 2001 and 2004. For the rest of the vegetation seasons the total PI is c. $10000-12000$. The dominant pollen type is Pinus diploxylon with values ranging from 2300 (1994) to 13780 (1997). The highest value for Pinus pence (3200) is recorded for year 1995 followed by a decrease till year 2000. Picea influx values are usually below 1000 although at an interval of 2-3 years they increase nearly twice (1994, 1999, 2004, 2007). Only one distinct maximum is recorded for Abies pollen in year 2004 (1750 grains $\mathrm{cm}^{-2}$ year $\left.^{-1}\right)$. There are three clear maxima for Fagus, 4000 (1994), 3780 (1999) and 2200 (2001), respectively, coinciding with those for Picea, with an intervening 2-3 years of low pollen. A similar trend is observed for the deciduous tree taxa like Corylus, Carpinus betulus, Alnus, and partly Quercus. The herb pollen taxa (NAP) are rather diverse with low influx values. Relative high PI values are recorded for Poaceae for years 1995 (above 2000 grains $\mathrm{cm}^{-2}$ year ${ }^{-1}$ ) and 1999, compared to an average annual value of c. 500. In some years the presence of Acbillea-type, Rumex, 
Cichoriaceae and Apiaceae pollen should be noted (Figure 3).

Trap BRL3 (Rila Mts., 1840 m a.s.I.)

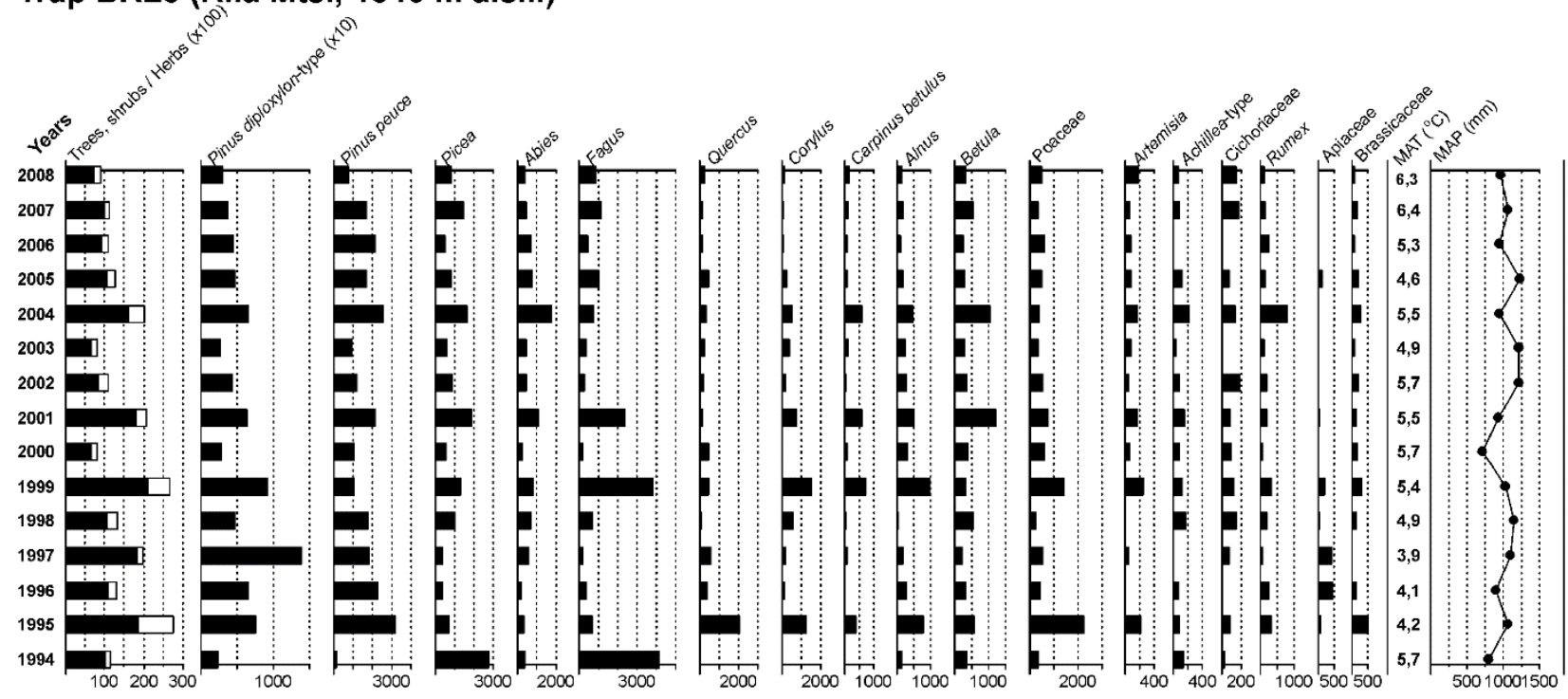

Figure 3. Pollen influx (grains $\mathrm{cm}^{-2}$ year $^{-1}$ ) recorded in pollen trap BRL3 (1994-2008).

The dataset from trap BRL-4 comprises 8 years, usually every second year, as the trap was restored several times. The highest total PI was recorded in 1997 (32230 grains $\mathrm{cm}^{-2}$ year ${ }^{-1}$ ) when for most of the taxa it was a big pollen year, except for Fagus. The greatest share is contributed by Pinus diploxylon-type (15000), followed by Picea (2250) and Alnus (1750). Starting from year 2000 a decline for the PI of Pinus pence (1600$500)$ is observed and for Juniperus pollen from year 2003. Most deciduous tree taxa (Quercus, Alnus, Betula) are well-represented in year 2005. Likewise trap BRL-3, Fagus dominates in year 1994 with 5700 grains cm ${ }^{2}$ year $^{-1}$. The variety of NAP types reflects the more open vegetation of the site with subalpine communities dominated by Poaceae (2500, year 1997), with occasional high values for Rumex, Apiaceae, Cichoriaceae and Scrophularia-type pollen in years 1997 and 1998 (Figure 4). 


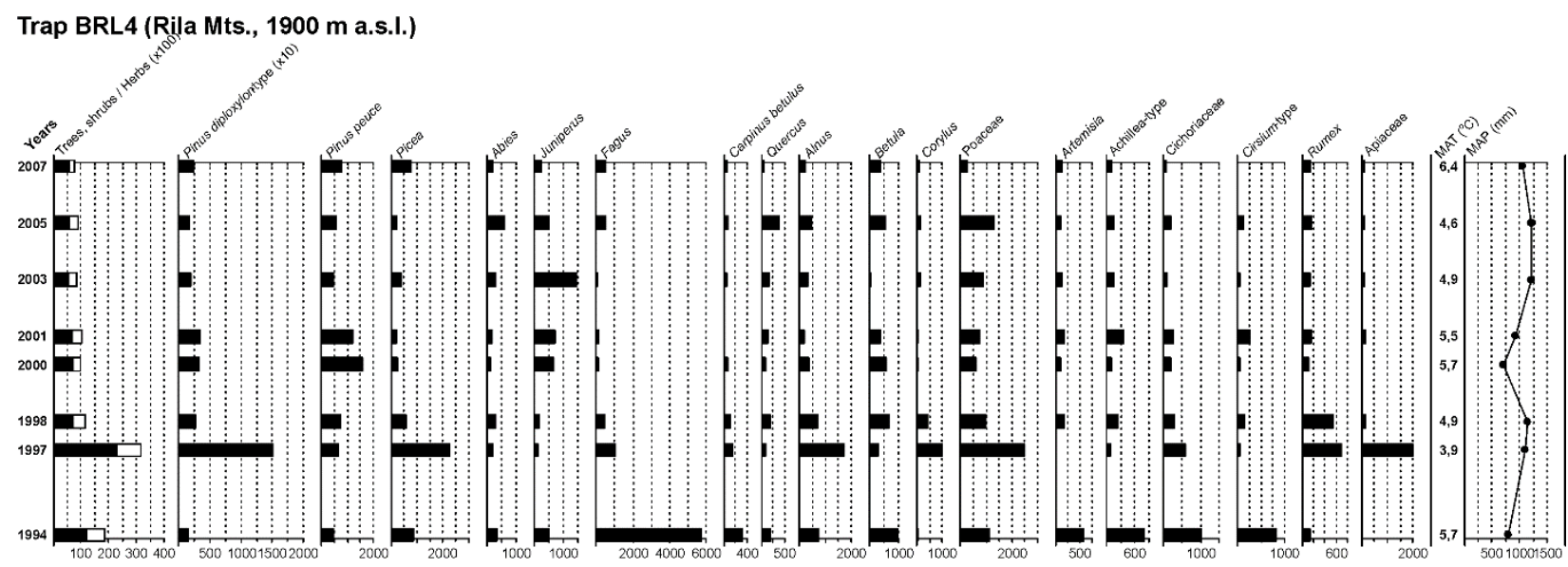

Figure 4. Pollen influx (grains $\mathrm{cm}^{-2}$ year $^{-1}$ ) recorded in pollen trap BRL4 (1994-2007).

\section{North slope - pollen traps BRL-8, BRL- 6 and BRL-7}

Trap BRL-8 has monitored the changes in the PI for seven successive years (2000-2006). The highest total PI is recorded for years 2003 (23420 grains $\mathrm{cm}^{-2}$ year $\left.^{-1}\right)$ and 2005 (21000), and the lowest for year 2001 (5170). The contributors with the highest values in year 2003 are Pinus diploxylon-type (16700) and Picea (4660), while Pinus peuce reaches a maximum of 1420 in year 2005. It Trap BRL8 (Rila Mts., $1800 \mathrm{~m}$ a.s.I.) is worth to mention that the maximal value of Fagus (750) is established in year 2001. Deciduous tree taxa such as Betula, Alnus, Corylus are present with higher PI values in two vegetation seasons (2004, 2006) when the input from the coniferous trees is lower. The share of NAP taxa is rather low, in some years the presence of Apiaceae (2005), Brassicaceae (2006), Ranunculus-type (2000) pollen, and spores of Polypodiaceae (2005) is a bit higher (Figure 5).

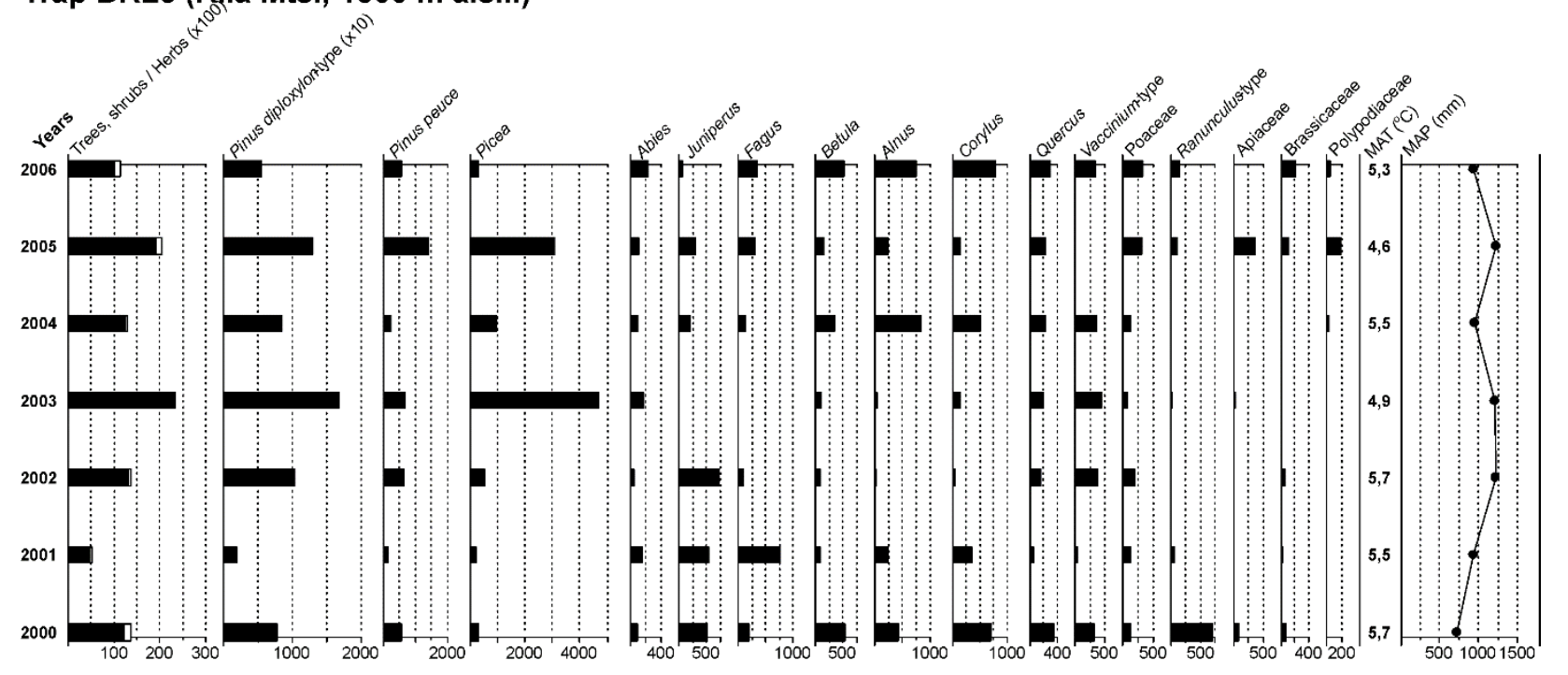

Figure 5. Pollen influx (grains $\mathrm{cm}^{-2}$ year $^{-1}$ ) recorded in pollen trap BRL8 (2000-2006).

In trap BRL-6 the average total PI is c. 10000 grains cm cmear $^{-1}$. An exception is year 2003 when it reaches 21700 grains $\mathrm{cm}^{-2}$ year ${ }^{-1}$ contributed mainly by Pinus diploxylon- type (12470), Picea (4930) and Quercus (670). Since year 1999 a tendency is visible for a gradual decline of Pinus peuce values from 1700 to 260 (year 2008). The participation of 
Fagus in the pollen trap is quite variable, ranging from minimal values (35 and 85 for years 2006 and 2000, respectively) to a maximum of 1770 (year 2008). Deciduous tree pollen is also present (Carpinus betulus, Corylus, Quercus) which is evidently a result of efficient upslope air transport, while the participation of Betula (660-1330) reflects the presence of groups of birch in the ecotone zone between the coniferous forests and the subalpine plant communities. Of particular interest is the appearance of Epilobium-type pollen and its increase since year 2002 from 880 grains $\mathrm{cm}^{-2}$ year ${ }^{-1}$ to 3280 (year 2008). The explanation is that in the early autumn of year 2000 a big forest fire burst out for several days in the vicinity to the trap. In the next years the species Epilobium angustifolium started to spread on the burnt out area as a pioneer element (Figure 6).

Trap BRL6 (Rila Mts., 1900 m a.s.I.)

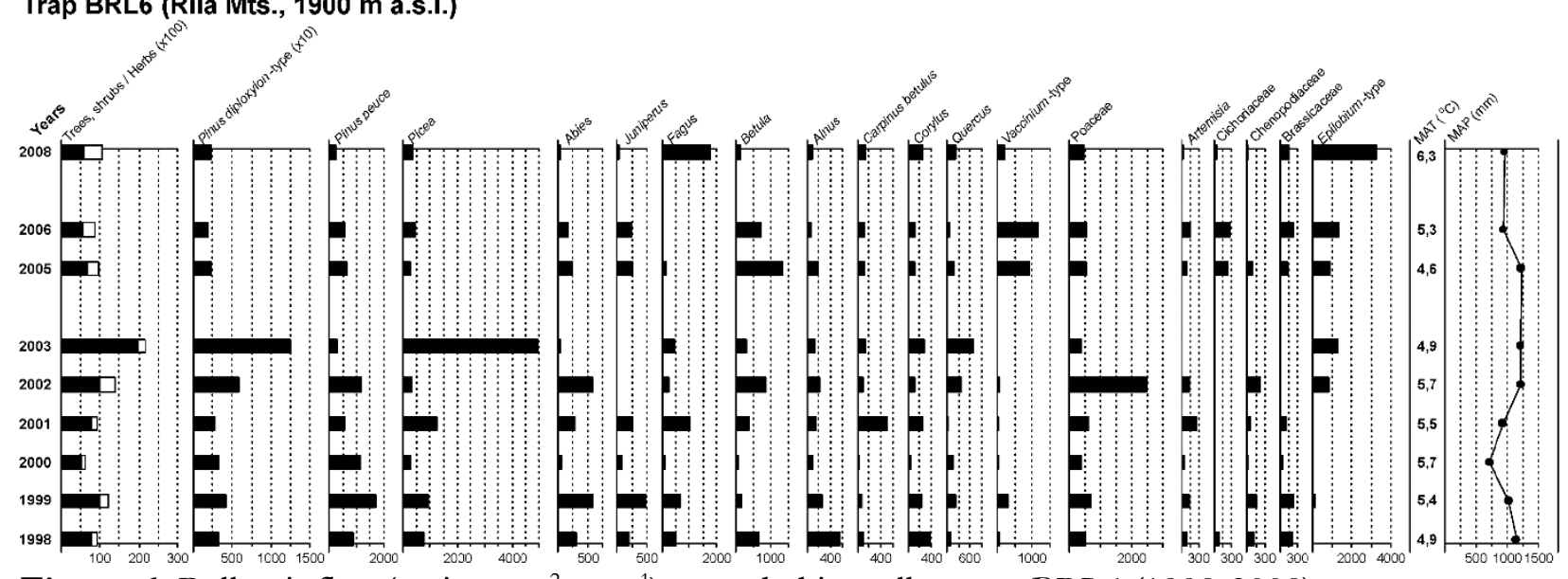

Figure 6. Pollen influx (grains $\mathrm{cm}^{-2}$ year $^{-1}$ ) recorded in pollen trap BRL6 (1998-2008).

Pollen trap BRL-7 placed in the subalpine zone in year 1998 functioned for nine vegetation seasons, except for year 2007. As expected, the highest pollen input originates from Pinus diploxylon-type (18304140 grains $\mathrm{cm}^{-2}$ year ${ }^{-1}$ ) comprising chiefly pollen of Pinus mugo, accompanied by Pinus peuce (800-1550) and Picea (680, year 1999) pollen. The PI of Fagus displays maximal values in years 1999 (640) and 2001 (970) like in the rest of the traps. Among the NAP taxa
Poaceae occupies a dominant position with average values c. $1000-1500$ grains $\mathrm{cm}^{-2}$ year ${ }^{1}$ reaching a maximum of 3040 in year 2002. The presence of Epilobium-type pollen is lower as getting away from the centre of the forest fire. The participation of other herb taxa (Artemisia, Achillea-type, Brassicaceae, Chenopodiaceae) remains relatively constant throughout the period of monitoring (19992008) (Figure 7). 
Trap BRL7 (Rila Mts., 2050 m a.s.I.)

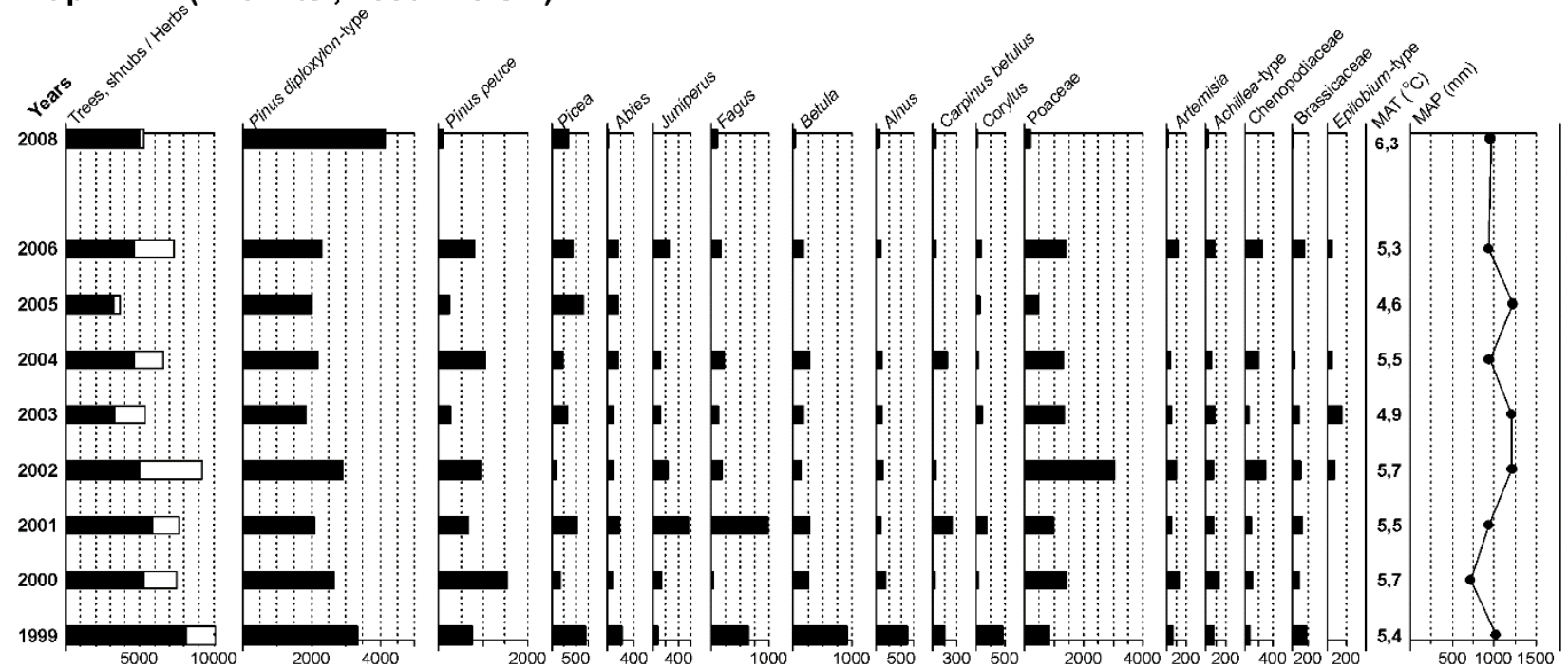

Figure 7. Pollen influx (grains $\mathrm{cm}^{-2}$ year $^{-1}$ ) recorded in pollen trap BRL7 (1999-2008).

\section{DISCUSSION AND CONCLUSIONS}

The longest continuous picture of pollen production and deposition in the study area for the entire 15 years' period of observation is obtained from trap BRL-3. The most abundant pollen taxon is Pinus diploxylon-type, although the proportion of Pinus sylvestris in the surrounding vegetation is only $20 \%$ (other species which produce this pollen type are Pinus mugo present at higher altitudes, and Pinus nigra small planted stands at a much lower altitude). Apart from several years with high PI values (1997, 1999 and 2004), the general trend since year 1999 is towards diminishing the presence of this pollen type. The minimal input of Pinus diploxylon-type pollen has occurred during the seasons 1994 and 2000 when the lowest amount of MAP $793 \mathrm{~mm}$ and $718 \mathrm{~mm}$, respectively, and MAT of $5.7^{\circ} \mathrm{C}$ were recorded. Despite that Pinus peuce is more abundant in the forest around trap BRL-3 its PI values are several times lower compared to those of Pinus diploxylon-type. The same year 2000 appeared also unfavorable for the pollen production of all coniferous and deciduous tree species.
The data from pollen trap BRL-4 which functioned in the ecotone zone between the coniferous and subalpine vegetation belts show rather uniform annual values of the total PI c. 10000 except for year 1997 as already mentioned. The participation of nearly all tree taxa in the trap is in conformity with their proportions in the surrounding vegetation. Compared to trap BRL-3 the relatively dry year 2000 has not affected the production and deposition of Pinus peuce pollen originating from populations growing around the timber-line. This result confirms the high ecological plasticity of this Balkan endemic tree species (Velchev and Russakova 1986) which requires lower temperatures and high air humidity as optimal conditions for its growth.

Of interest is also the annual participation of Picea and Fagus pollen in traps BRL-3 and BRL-4 (Figures 3, 4 and 8). The PI values of the first species are in accordance with its participation in the vegetation surrounding the traps, 20\% and $10 \%$, respectively. When compared to Pinus peuce, the influx values of Picea are a bit lower, but both species demonstrate similar tendency in pollen deposition throughout 
the entire period of observation (trap BRL3). Evidently, nearly every three-four years (1994, 1997, 2001, 2004 and 2007) the pollen input of Picea doubles and these maxima are correlated positively with relatively high MAP values of at least $1000 \mathrm{~mm}$ (Raev 2006).
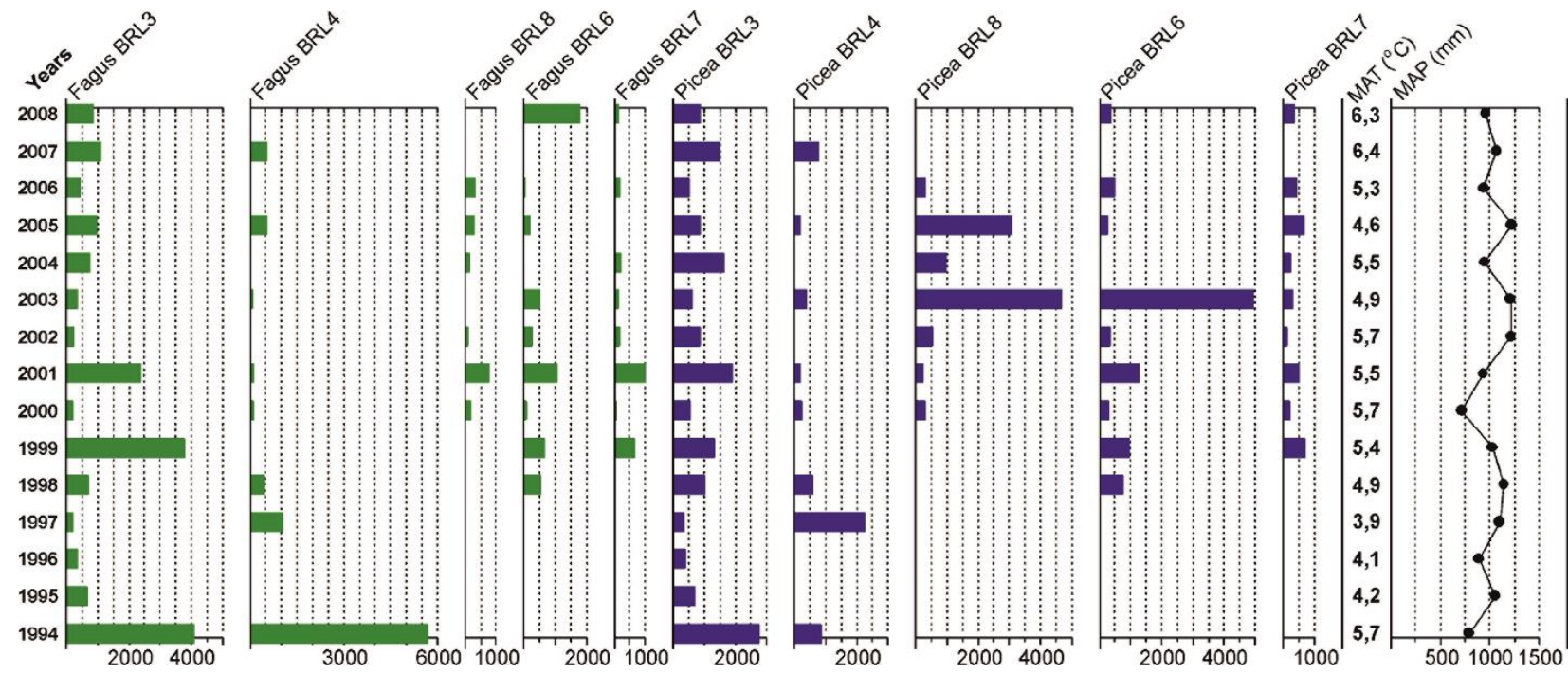

Figure 8. Pollen influx (grains $\mathrm{cm}^{-2}$ year-1) for Fagus and Picea recorded in all pollen traps (19942008).

The species Fagus sylvatica grows at lower altitudes in the Rila Mts. and the distance to the nearest individuals from trap BRL-3 is c. $400 \mathrm{~m}$. Beech demonstrates very good pollen dispersal upslope, better than has previously been considered (Tonkov et al. 2001, Pidek et al. 2010). There are two clear maxima $(1994,1999)$ separated by four years of much lower PI and another maximum in year 2001 when the MAP value was c. $1000 \mathrm{~mm}$. The years 2005 and 2007 can also be considered to some extent favorable for the flowering of beech (Figures 3 and 4). The report from the Rila State Forestry Farms presented abundant production of beech seeds for year 2007 (Tonkov et al. 2009). The pollen and seed production of Fagus sylvatica in temperate regions varies from year to year with a cyclicity of several years (Broström 2002). The trapping results from the Rila Mts. probably reflect such cyclicity in abundant flowering known for beech, combined with efficient pollen dispersal upslope by ascending winds, so that the share of this lower altitude pollen near and above the tree-line can be considerable.

The traps BRL8 and BRL6 placed on a north slope have monitored the pollen production and deposition for the period 1998-2008 in the upper part of the coniferous belt dominated by Picea abies. The most abundant pollen taxon in these traps is again Pinus diploxylon-type despite that the presence of Pinus sylvestris in the recent vegetation around trap BRL8 is below 10\% (Table 1). At the tree-line the main source of this pollen type becomes Pinus mugo (50\% in the vegetation around trap BRL6) with average annual PI not exceeding 5000 grains $\mathrm{cm}^{-2}$ year ${ }^{-1}$ (Figures. 5 and 6). It is well known that dwarf-pine and Scotts pine are overproducers of pollen which is effectively distributed to long distances from the source area (Faegri and Iversen 1989). In the subalpine zone (trap BRL7) the pollen input of Pinus mugo remains nearly constant throughout the period of observation. In 
year 2003 pollen of both Pinus diploxylon-type and Picea showed maximal values. The other conifers Pinus peuce and Abies alba are adequately present in the pollen traps on the north slope in respect to their distribution in the vegetation cover. Likewise the situation on the south slope the dry year 2000 appeared unfavorable for the pollen production of all coniferous and deciduous tree species.

The content of Fagus pollen in the three traps on the north slope increases in year 2001 and in trap BRL-7 in year 2008 (Figure 8). It is worth to point out that in the first year after the fire (2001) the higher quantity of deciduous tree pollen deposited from Fagus, Carpinus, Corylus and Quercus could be explained by an easier pollen transport from altitudes below $1200 \mathrm{~m}$ where these trees grow. The damages in the coniferous forests from the fire have diminished their filter effect. The first signs of plant regeneration on the burnt out terrains were monitored in year 2002. The quantity of Poaceae pollen (trap BRL6) sharply rises together with pollen of Betula. The appearance of pollen of Epilobium angustifolium indicates colonization of open areas after forest fires (Figure 6).

The results from this long-term pollen monitoring experiments in forest communities in the Rila Mts. could be compared with similar studies which were conducted within the same time interval.

The annual PI produced by representative coniferous communities dominated by Picea abies (1450-1750 m a.s.l.) on the territory of the Borovets State Forest Farm (northwestern Rila Mts.) was monitored for a three-year period of observation (2006-2008) (Tonkov et al. 2009). The results from the three traps showed that pollen of Pinus diploxylon-type (Pinus mugo, Pinus sylvestris) was the most abundant, together with a relatively constant presence of Picea, Abies and Pinus pence pollen. Pollen of Fagus was well represented in the traps, particularly in two successive years (2007 and 2008) as a result of abundant flowering, effective dispersal upslope and high deposition. In year 2007 that probably happened as a compensating response to the drier year 2006. This result coincides with the information from trap BRL3 (year 2007) and trap BRL7 (year 2008) (Figure 8). The most favorable year for the pollen production of the coniferous trees (Pinus sylvestris, Pinus mugo, Picea abies and Abies alba) on the territory of the State Forest Farm was 2007 as a result of the combined positive effect of higher mean annual precipitation and temperature. However, the total PI started to decrease since year 2006 and this trend was particularly obvious in year 2008 when pollen overproducers like Pinus mugo and Pinus sylvestris showed rather low deposition values. The trapping results confirmed the conclusions of Raev (2006) that in the northwestern Rila Mts. optimal conditions exist for the growth of Picea abies. These forests do not suffer from drier interannual periods and the hydrothermic conditions appear favorable for their stable bioproductivity.

The pollen trapping results from the Rila Mts. could be partly compared with data from the Central Stara Planina Mts. (Atanassova 2007) (Figure 1, site 1). In Shipchenska Mt. five pollen traps functioned for four consecutive years (20022005) along an altitudinal transect (639-1310 $\mathrm{m}$ a.s.l.) where most abundant are forests of Fagus sylvatica or mixed with Picea abies, forests of Pinus sylvestris, and deciduous oak woods in the foothills. The most favorable year for the growth of the coniferous (Pinus sylvestris, Picea abies) and deciduous (Fagus sylvatica, Carpinus betulus, Betula, Corylus) trees was 2003. Pinus diploxylon-type was overrepresented in all pollen traps which can 
be explained by the absence of clearly delineated vegetation belts. The highest PI values for Fagus were recorded also in year 2003 reaching c. 3000 grains $\mathrm{cm}^{-2}$ year ${ }^{-1}$ unlike the situation in the Rila Mts. for the same year. This result presumes that the cyclicity in the flowering of beech, where observed, depends mainly on the local climatic conditions.

A series of pollen traps were placed in the western Rhodopes Mts. (south Bulgaria) at $1550 \mathrm{~m}$ a.s.l in the coniferous belt (Figure 1, site 2) to study in details how the participation of Pinus sylvestris and Picea abies in the surrounding vegetation is reflected in the annual PI for two successive years 2002 and 2003 (Lazarova et al. 2006). The results demonstrated that pollen of Pinus diploxylon-type was dominant in the pollen traps while pollen of Picea was underrepresented. Another important conclusion from this study was that year 2003 appeared more favorable for pollen production.

In four places of the Strandzha Mts. In southeast Bulgaria (Figure 1, site 3) with different vegetation types pollen traps were placed to monitor the annual pollen influx of the main tree species (Quercus, Fagus orientalis and Carpinus betulus) in the course of three years (2002-2004) (Filipova-Marinova et al. 2007). The results revealed that year 2003 appeared favorable for the flowering and deposition of oak and beech pollen, the PI values of Fagus orientalis reached a maximum of c. $3500 \mathrm{~cm}^{-2}$ year $^{-1}$. As already mentioned above, year 2003 was not favorable for the pollen production of Fagus sylvatica in the Rila Mts. but there was a good conformity with the PI values of beech reported from the Central Stara Planina Mts. for the same year.

On a European scale the annual PI values of Fagus (high or low) monitored along a N-S transect from Poland to southeast Bulgaria in the course of the time interval 1998-2008 occurred most frequently in parallel within each region and often in two neighbouring regions. Regional occurrence of beech-dominated forests was reflected by influx value of c. 1400 grains $\mathrm{cm}^{-}$ ${ }^{2}$ year $^{-1}$ and local abundance very close to pollen traps by c. 2400 grains $\mathrm{cm}^{-2}$ year ${ }^{-1}$. High deposition of beech pollen was recorded in 2006 in nearly all regions with the exception of Bulgaria and this was also a mast year (Pidek et al. 2010).

The long-term pollen monitoring study (1994-2008) in the Rila Mts. throws light on the driving mechanisms behind pollen production, dispersal patterns and deposition in a mountainous area. The trapping experiment highlighted the annual differences in the pollen production of the main tree species growing on north and south slopes at elevations between 1800 and $2050 \mathrm{~m}$ a.s.l. The following main conclusions can be outlined:

1. The results from all pollen traps indicate a gradual decline for the total PI values since year 2004 to c. 10000 grains cm ${ }^{2}$ year $^{-1}$.

2. The most favorable years for the pollen production and effective dispersal of pollen grains of the coniferous trees (Pinus sylvestris, Pinus mugo, Picea abies and Pinus peuce) were 1997, 1999, 2003, and partly 2005, as a result of the combined positive effect of the annual precipitation and temperature values.

3. In the case of Picea abies, the tree which dominates in the recent vegetation of the coniferous belt, the comparatively constant pollen influx of c. 1000 grains $\mathrm{cm}^{-2}$ year $^{-1}$ (with the exception in the years with maximal records) confirms that in the northwestern Rila Mts. optimal ecological conditions exist for the growth of spruce forests.

4. The species Fagus sylvatica, which is found at lower altitudes in the Rila Mts., 
demonstrates very good capabilities of pollen dispersal upslope and the trapping results reveal a cyclicity in its flowering. The most favorable years with maximal PI values recorded were 1994, 1999, 2005 and 2007. The comparison with similar studies from other parts of the country suggests that the cyclicity in the flowering of beech depends mainly on the local climatic conditions.

5. The pollen trapping results could be successfully applied to help monitor the future trends in forest development in relation to climate changes and local anthropogenic disturbances.

\section{Acknowledgements}

This paper is a contribution to the Pollen Monitoring Programme. It is our pleasure to dedicate it to the founder and first leader of this international scientific project Prof. Sheila Hicks (Oulu, Finland) for her enthusiasm, friendship, support and cooperation.

\section{References}

Atanassova, J. (2007). Pollen deposition in moss polsters and pollen traps in the Central Stara Planina Mts. (2002-2005). Phytologia Balcanica 13 (2), 223-228.

Beug, H.-J. (2004). Leitfaden der Pollenbestimmung für Mitteleuropa und angrenzende Gebiete. Verlag Dr. Friedrich Pfeil, München.

Birks, H.J.B. (1996). Contribution of Quaternary palaeoecology to nature conservation. Journal of Vegetation Science 7, 89-98.

Bozilova, E., Kalmukov, K., Lazarova, M., Tonkov, S. (2012). Pollen monitoring in Tilia forests in Northeastern Bulgaria. In: Proceedings of VII

th National Botanical Conference. Bulgarian Botanical Society, Sofia, pp. 443-453.

Broström, A. (2002). Estimating source area of pollen and pollen productivity in the cultural landscapes of southern Sweden - developing a palynological tool for quantifying past plant cover. LUNDQUA Thesis 46, Lund University, Lund, Sweden.
Faegri, K., Iversen, J. (1989). Textbook of Pollen Analysis. 4-th Edition. John Wiley \& Sons, Chichester.

Filipova-Marinova, M., Bozilova, E., Hicks, S. (2007). Pollen monitoring of forest communities in the Strandzha Mts. Bulletin du Musee National de Varna 41(56), 135-155.

Filipova-Marinova, M., Kvavadze, E., Connor, S., Sjögren, P. (2010). Estimating absolute pollen productivity for some European Tertiary-relict taxa. Vegetation History and Archaeobotany 19(4), 351-364.

Gerasimidis, A., Panajiotidis, S., Hicks, S., Athanasiadis, N. (2006). An eight-year record of pollen deposition in the Pieria mountains $(\mathrm{N}$ Greece) and its significance for interpreting fossil pollen assemblages. Review of Palaeobotany and Palynology 141(3-4), 231-243.

Giesecke, T., Fontana, S.L., van der Knaap, W.O., Pardoe, H.S., Pidek, I.A. (2010). From early pollen trapping experiments to the Pollen Monitoring Programme. Vegetation History and Archaeobotany. 19(4): 247-258.

Grimm, E. 2011. TGView ver. 1.17.5, Illinois State Museum, Illinois, USA.

Hicks, S. (1996). The feasibility of using pollen deposition data as climatic indices. Palaoklimaforschung 20, 173-187.

Hicks, S. (2001). The use of arboreal pollen deposition values for delimiting tree-lines in the landscape and exploring models of pollen dispersal. Review of Palaeobotany and Palynology 117(1-3), 1-29.

Hicks, S., Ammann, B., Latalowa, M., Pardoe, H., Tinsley, H. (1996). European Pollen Monitoring Programme: Project Description and Guidelines. University of Oulu, Oulu.

Hicks, S., Tinsley, H., Huusko, A., Jenssen, C., Hatterstrand, M., Gerasimidis, A., Kvavadze, E. (2001). Some comments on spatial variation in arboreal pollen deposition: first records from the Pollen Monitoring Programme (PMP). Review of Palaeobotany and Palynology 117, 183-195.

Karlıoğlu, N., Caner, H., Akkemik, U. (2014). Modern pollen distribution at Iğneada waterlogged forests between the periods September 2007 - August 2009. Eurasian Journal of Forest Science 2 (2), 7-17.

Karlıoğlu, N., Caner, H., Akkemik, U., Kose, N., Kindap, T. (2015). Modern pollen monitoring of native trees in Belgrad forest, Istanbul (Northwestern Turkey). Comptes rendus de l'Academie bulgare des Sciences 68(1), 39-48. 
Lazarova, M., Petrova, M., Jordanova, M. (2006). Pollen monitoring in surface samples in mosses and pollen traps from the Beglika region (W Rhodopes). Phytologia Balcanica 12(3), 317-326.

Moore, P., Webb, J. A., Collinson, M. E. (1991). Pollen Analysis. 2 ${ }^{\text {-nd }}$ Edition, Blackwell, Oxford.

Pardoe, H., Giesecke, T., Van der Knaap, W.O., Svitavska-Svobodova, H., Kvavadze, E., Panajiotidis, S., Gerasimidis, A., Pidek, I., Zimny, M., Swieta-Musznicka, J., Latałowa, M., Noryskiewicz, A., Bozilova, E., Tonkov, S., Filipova-Marinova, M., Van Leeuwen, J.F.N., Kalnina, L. (2010). Comparing pollen spectra from modified Tauber traps and moss samples: examples from a selection of woodlands across Europe. Vegetation History and Archaeobotany 19(4), 271-283.

Pidek, I.A., Svitavska-Svobodova, H., Van Der Knaap, W.O., Noryskiewicz, A.M., FilbrandtCzaja, A., Noryskiewicz, B., Latalowa, M., Zimny, M., Swieta-Musznicka, J., Bozilova, E., Tonkov, S., Filipova-Marinova, M., Poska, A., Giesecke, T., Gikov, A. (2010). Variation in annual pollen accumulation rates of Fagus along a N-S transect in Europe based on pollen traps. $V$ egetation History and Archaeobotany 19 (4), 259270.

Raev, I. (2006). Climatic conditions in representative forests of Picea abies (L.) Karsten in the Rila Mountain. In: Raev, I. (Ed.), Environment and Structure of the Norway Spruce Forests in the Rila Mountain, Pensoft Publishers, SofiaMoscow, pp. 1-20.

Seppa, H., Hicks, S. (2006). Integration of modern and past pollen accumulation rate (PAR) records across the arctic tree-line: a method for more precise vegetation reconstructions. Quaternary Science Reviews 25, 1501-1516.
Stockmarr, J. (1971). Tablets with spores used in absolute pollen analysis. Pollen et Spores 13, 614621.

Tonkov, S., Hicks, S., Bozilova, E., Atanassova, J. (2001). Pollen monitoring in the Central Rila Mountains, Southwestern Bulgaria: case studies from pollen traps, surface samples for the period 1994-1999. Review of Palaeobotany and Palynology 117,167-182.

Tonkov, S., Bozilova, E., Pavlova, D. (2004). Pollen monitoring in the Northwestern Rila Mountains, Southwestern Bulgaria. In: Proceedings of the $2^{\text {nd }}$ Congress of Ecologists of the Republic of Macedonia with International Participation. Special issues of Macedonian Ecological Society, Skopje, vol. 6, pp. 53-56.

Tonkov, S., Stoyanova, N., Bozilova, E. (2009). Pollen monitoring experiment in the coniferous forests of NW Rila Mts (Bulgaria). Phytologia Balcanica 15(3), 333-336.

van der Knaap, W.O., van Leeuwen, J.F.N., Svitavska-Svobodova, H., Pidek, I.A., Kvavadze, E., Chichinadze, M., Giesecke, T., Kaszewski, B.M., Oberli, F., Kalnina, L., Pardoe, H.S., Tinner, W., Ammann, B. (2010). Annual pollen traps reveal the complexity of climatic control on pollen productivity in Europe and the Caucasus. Vegetation History and Archaeobotany 19(4), 285-308.

Velchev, V., Russakova, V. (1986). Ecological peculiarities and phytocenological characteristics of Pinus peuce Griesb. in the Pirin and Rila Mountains. Annual of Sofia University. Faculty of Biology 80(2), 58-93.

\section{Expanded Abstract}

Поленовият мониторинг предоставя информация за състоянието на растителните екосистеми които продуцират поленов АъжА. Връзката съвременна растителност/полен зависи от редица фактори, найважните от които са поленовата продукция, разсейването, отлагането и запазването на поленовите зърна и спори, съставът на заобикалящата растителност, както и антропогенното въздействие. От своя страна поленовата продукция на отАелните растителни видове се определя от еколого-физиологическите им особености, които зависят и от основни климатични показатели като температура и валежи за съответния вегетационен сезон. Този методичен подход е използван при настоящето проучване проведено в Северозападна Рила за периода 1994-2008 г. Пет капана-уловители на полен бяха поставени по южен и северен склон в диапазона 1800-2050 м н.в. в иглолистния и субалпийския растителни пояси. Капните бяха ежегодно зареждани и събирани за обработка през есента в края на съответния вегетационен сезон. С използването на спорово-поленовия анализ е изчислен годишния поленов инфлукс (брой поленови зърна $\mathrm{cm}^{-2}$ год $\left.{ }^{-1}\right)$ на основни дървесни и тревисти видове, който е представен под формата на поленови диаграми. Проведеното изследване в течение на 15 вегетационни сезона разкрива ежегодните разАичия в поленовата 
продукция на основни горски иглолистни (Pinus sylvestris, Pinus mugo, Picea abies, Pinus peuce, Abies alba) и широколистни (Fagus sylvatica, Quercus sp., Corylus sp., Betula pendula) видове. Резултатите от поленовите капани показват тенденция към постепенно намаляване на общия поленов инфлукс след 2004 г. Найблагоприятните години за поленовата продукция на иглолистните видове с последващото й ефективно разсейване и отлагане са 1997, 1999, 2003 и отчасти 2005 в резултат на съчетанието на оптимално количество валежи и температурни стойности. Относно обикновения смърч, който се явява основен Аоминант в иглолистните гори, сравнително постоянните стойности на ежегодния му поленов инфлукс потвържАават заключенията на месовъдите, че в проучвания район на планината екологичните условия са оптимални за неговото развитие. Поленът на обикновения бук се разпространява много Аобре към по-големи надморски височини и установените максимални стойности на поленовия инфлукс отразяват определена цикличност в цъфтежа на този широколистен дървесен вид през няколко години (1994, 1999, 2005 и 2007). Получените резултати могат успешно Аа се прилагат при мониторинг на тенденциите в развитието на горските екосистеми във връзка с измененията на климата и антропогенното въздействие в планинските райони.

Submitted: 22.11.2015

Accepted: 18.01.2016 